\title{
The Validity of the Features of the Offer for Customers in the Area of the Product: the Comparison of the Assessment of Dairy Cooperatives from the Świętokrzyskie and Małopolskie Provinces
}

\author{
Izabela KONIECZNA \\ The Jan Kochanowski University in Kielce, Kielce, Poland \\ izabela.konieczna@ujk.edu.pl
}

\begin{abstract}
The aim of the article is to analyze the validity of the features of the offer for customers in the area of the product in the assessment of dairy cooperatives from the Świętokrzyskie and Małopolskie Provinces. Cooperatives' executives were asked to indicate features of the offer, which are valid, in their opinion, for such customers as consumers, companies - users (gastronomy), wholesalers, independent retail grocery stores, large retail chains, local retail chains, intermediary agents in food trade, other dairies, and other institutional purchasers. Cooperatives' representatives had to assess such product features as: product components, naturalness of the product, ecology of the product, healthiness of the product, the nutritional value, the width of the assortment, differentiation, product specialization. The results of the research show that cooperatives from Świętokrzyskie and Małopolskie Provinces rather differently assess the validity of the features of the offer for customers in the area of the product.
\end{abstract}

Keywords: Features of the Offer, Product, Cooperatives.

\section{Introduction}

Product refers to the goods and services the company offers to its customers. Apart from the physical product itself, there are elements associated with the product that customers may be attracted to. Among many attributes of the product such as quality, options, services, warranties, brand name, there are also features that attract the customer. However, as research results show $[9,10]$ different kind of the offer can attract the customers and every company should know what kind of the features of the product are valid. Therefore, the aim of the article is to analyze the validity of the features of the offer for customers in the area of the product in the assessment of dairy cooperatives from the Świętokrzyskie and Małopolskie Provinces. Cooperatives' representatives had to assess such product features as: product components, naturalness of the product, ecology of the product, healthiness of the product, the nutritional value, the width of the assortment, differentiation, product specialization in 
terms of the validity for such customers as consumers, companies - users (gastronomy), wholesalers, independent retail grocery stores, large retail chains, local retail chains, intermediary agents in food trade, other dairies, and other institutional purchasers.

\section{A product - the theoretical background}

A product may be defined as everything, both favorable and unfavorable, that a person receives in an exchange [14]. Broadly defined, a product is anything that can be offered to a market for attention, acquisition, use, or consumption that might satisfy a want or need [11]. A product is, to the potential buyer, a complex cluster of value satisfactions [15]. Products include physical objects but also services, events, persons, places, organizations, ideas, or mixed of these entities. Services are products that consist of activities, benefits, or satisfactions offered for sale that [11] have four unique characteristics that distinguish them from goods. Services are intangible, inseparable, heterogeneous, and perishable [14]. Products fall into one of two general categories. Products purchased to satisfy personal and family needs are consumer products. Those bought to use in a company's operations, to resell or to make other products are business products [18]. As claim Kotler, Keller, Brady, Goodman and Hansen products can be classified in several ways. In terms of durability and reliability, products can be non-durable goods, durable goods or services. In the consumer goods category [12], where a product is bought to satisfy on individual's personal wants [14], products are:

- convenience goods (staples, impulse goods and emergency goods) [12]. A convenience product is a relatively inexpensive item that merits little shopping effort [14] and is normally marketed through many retail outlets [18],

- shopping goods (homogeneous and heterogeneous) [12]. A shopping product is a product that requires comparison shopping because it is usually more expensive than a convenience product and is found in fewer stores [14],

- specialty goods [12]. A specialty product is a particular item for which consumers search extensively and are very reluctant to accept substitutes. An unsought product is a product unknown to the potential buyer, or a known product that the buyer does not actively seek [14],

- unsought goods [12]. Unsought products are products purchased when a sudden problem must be solved, product of which customers are unaware and products that people do not necessarily think of purchasing [14].

In the industrial (business) goods category, products fall into one of three categories: materials and parts (raw materials and manufactured materials and parts), capital items (installations and equipment), or supplies and business services (operating supplies, maintenance and repair items, maintenance and repair services, and business advisory services) [12].

Determining and satisfying the needs of customers through products that have value and accessibility and whose features are clearly communicated is the general 
purpose of any business [2]. Products are always usually some combination of tangible elements and intangible elements [18]. While tangible features are obvious, the intangible product features are hard to measure objectively, yet they may be important determinants of consumer buying decisions [1]. The product needs to have the right features for the right market [3]. Product features are specific design characteristics that allow the product to perform certain tasks. By adding or subtracting features, a company can differentiate its products from those of the competition [18].

Consumers buy products to satisfy their personal wants, whereas business buyers seek to satisfy the goals of an organization [18], so the product manager need to classify the types of customers, and to determine who the primary customers are [4], and as a result which customers are the most important [7,8]. When consumers purchase a product, they are really buying the benefits and satisfaction they think the product will provide [18], so when consumers evaluate products or services, they often search for diagnostic information on specific product benefits [16]. Information from marketing research efforts and from databases can help in assessing customers' product design preferences. Being able to meet customers' desires for product design style and features at process they can afford is crucial to a product's long-term success [18].

\section{The empirical verification of the validity of the features of the offer for customers in the area of the product}

Research on the validity of the features of the offer for customers in the area of the product was conducted in dairy cooperatives from the Świętokrzyskie and Małopolskie Provinces, which had given their consent. The research tool was an interview questionnaire. The questionnaire was sent to all dairy cooperatives from the Świętokrzyskie and Małopolskie Provinces. Due to the willingness of representatives of cooperatives to participate in the research, interviews were conducted on a sample of $41 \%$ of dairy cooperatives from both provinces. Executives were asked to indicate features of the offer for customers, which are valid, in their opinion, for such customers as consumers, companies - users (gastronomy), wholesalers, independent retail grocery stores, large retail chains, local retail chains, intermediary agents in food trade, other dairies, and other institutional purchasers. The results of the interviews are presented in Tab. 1 and Fig. 1.

Basing on the research of importance of the types of customers of dairy cooperatives from Świętokrzyskie and Małopolskie Provinces [7], it is clear that cooperatives did not assessed the validity of the features of the offer for intermediary agents in food trade, other dairies, and other institutional purchasers, because they do not have such customers. The same situation is seen when analyzing the customers of dairy cooperatives from the Świętokrzyskie Province, because they do not have also such customers as independent retail grocery stores and large retail chains. 
Table 1. The results of the research of the validity of features of the offer for customers in the area of the product in the assessment of dairy cooperatives from the Świętokrzyskie and Małopolskie Provinces [8].

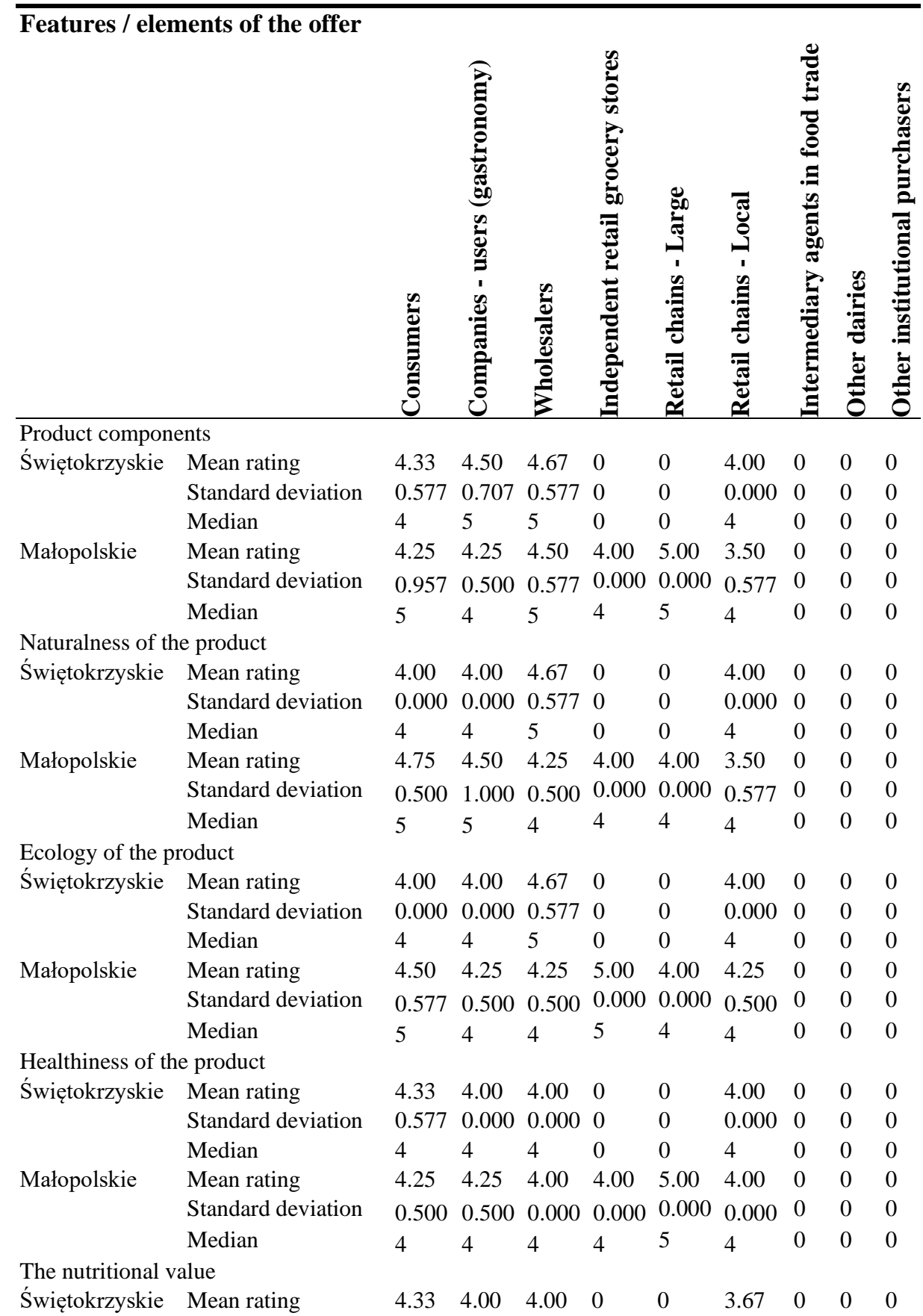




\begin{tabular}{|c|c|c|c|c|c|c|c|c|c|c|}
\hline & Standard deviation & 0.577 & 0.000 & 0.000 & 0 & 0 & 0.577 & 0 & 0 & 0 \\
\hline & Median & 4 & 4 & 4 & 0 & 0 & 4 & 0 & 0 & 0 \\
\hline \multirow[t]{3}{*}{ Małopolskie } & Mean rating & 3.25 & 4.25 & 4.00 & 3.00 & 4.00 & 4.50 & 0 & 0 & 0 \\
\hline & Standard deviation & 0.500 & 0.957 & 0.000 & 0.000 & 0.000 & 0.577 & 0 & 0 & 0 \\
\hline & Median & 3 & 5 & 4 & 3 & 4 & 5 & 0 & 0 & 0 \\
\hline \multicolumn{11}{|c|}{ The width of the assortment } \\
\hline \multirow[t]{3}{*}{ Świętokrzyskie } & Mean rating & 4.33 & 3.50 & 4.00 & 0 & 0 & 3.67 & 0 & 0 & 0 \\
\hline & Standard deviation & 0.577 & 0.707 & 0.000 & 0 & 0 & 0.577 & 0 & 0 & 0 \\
\hline & Median & 4 & 4 & 4 & 0 & 0 & 4 & 0 & 0 & 0 \\
\hline \multirow[t]{3}{*}{ Małopolskie } & Mean rating & 4.00 & 3.75 & 3.75 & 4.00 & 4.00 & 4.25 & 0 & 0 & 0 \\
\hline & Standard deviation & 0.000 & 0.500 & 0.500 & 0.000 & 0.000 & 0.957 & 0 & 0 & 0 \\
\hline & Median & 4 & 4 & 4 & 4 & 4 & 5 & 0 & 0 & 0 \\
\hline \multicolumn{11}{|l|}{ Differentiation } \\
\hline \multirow[t]{3}{*}{ Świętokrzyskie } & Mean rating & 4.33 & 4.00 & 4.33 & 0 & 0 & 4.00 & 0 & 0 & 0 \\
\hline & Standard deviation & 0.577 & 0.000 & 0.577 & 0 & 0 & 0.000 & 0 & 0 & 0 \\
\hline & Median & 4 & 4 & 4 & 0 & 0 & 4 & 0 & 0 & 0 \\
\hline \multirow[t]{3}{*}{ Małopolskie } & Mean rating & 4.25 & 4.50 & 3.75 & 3.00 & 3.00 & 3.75 & 0 & 0 & 0 \\
\hline & Standard deviation & 0.957 & 0.577 & 1.258 & 0.000 & 0.000 & 0.500 & 0 & 0 & 0 \\
\hline & Median & 5 & 5 & 4 & 3 & 3 & 4 & 0 & 0 & 0 \\
\hline \multicolumn{11}{|c|}{ Product specialization } \\
\hline \multirow[t]{3}{*}{ Świętokrzyskie } & Mean rating & 4.67 & 4.00 & 4.33 & 0 & 0 & 4.00 & 0 & 0 & 0 \\
\hline & Standard deviation & 0.577 & 0.000 & 0.577 & 0 & 0 & 0.000 & 0 & 0 & 0 \\
\hline & Median & 5 & 4 & 4 & 0 & 0 & 4 & 0 & 0 & 0 \\
\hline \multirow[t]{3}{*}{ Małopolskie } & Mean rating & 4.00 & 4.00 & 3.75 & 4.00 & 2.00 & 3.25 & 0 & 0 & 0 \\
\hline & Standard deviation & 1.414 & 0.816 & 0.500 & 0.000 & 0.000 & 0.957 & 0 & 0 & 0 \\
\hline & Median & 5 & 4 & 4 & 4 & 2 & 4 & 0 & 0 & 0 \\
\hline
\end{tabular}

Scale: $1-5$, where 5 - extremely important, 4 - very important, 3 - quite important, 2 - little important, 1 - completely unimportant, 0 - not applicable. 


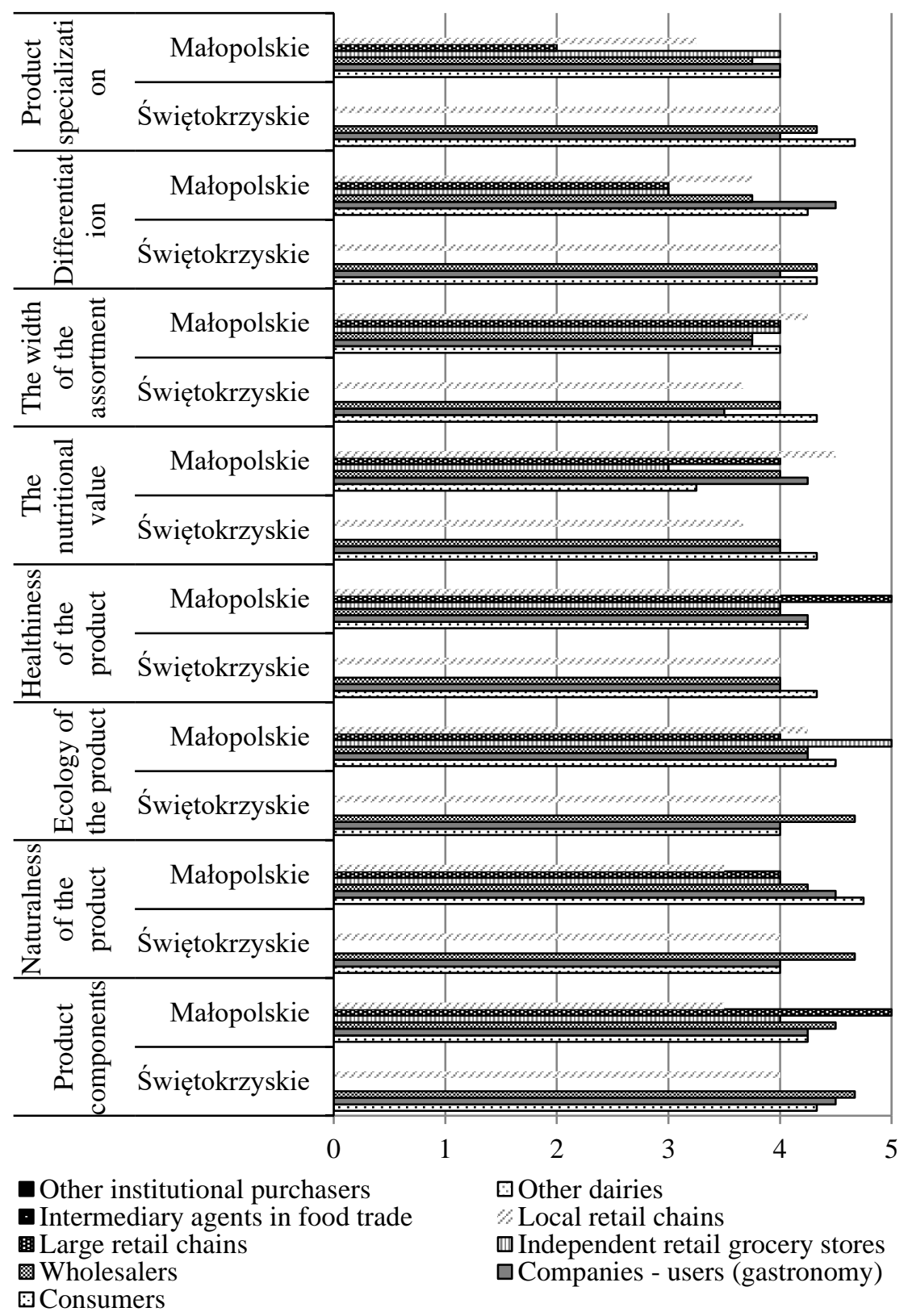

Scale: $1-5$, where 5 - extremely important, 4 - very important, 3 - quite important, 2 - little important, 1 - completely unimportant, 0 - not applicable.

Fig. 2. The mean rating of the validity of the features of the offer for customers in the area of the product in the assessment of dairy cooperatives from the Świętokrzyskie and Małopolskie Provinces. 
Taking into account the research results of the validity of the features of the offer for customers in the area of the product in the assessment of dairy cooperatives from the Świętokrzyskie and Małopolskie Provinces showed in Tab. 1 and Fig. 1 it can be seen that:

- Product components were considered as extremely important for wholesalers, and as very important for consumers and local retail chains both by cooperatives from Świętokrzyskie and Małopolskie Provinces. For companies - users (gastronomy) the product components were indicated as extremely important in the assessment of dairy cooperatives from Świętokrzyskie Province, and as very important in the assessment of dairy cooperatives from Małopolskie Province. In the same time cooperatives from Małopolskie Province assessed the validity of the features of the offer for independent retail grocery stores as very important, and for large retail chains as extremely important.

- Naturalness of the product was considered as extremely important for wholesalers in the assessment of dairy cooperatives from Świętokrzyskie Province, and for consumers and companies - users (gastronomy) from the point of view of cooperatives from Małopolskie Province. In the same time naturalness of the product was considered as very important for local retail chains both by dairy cooperatives from Świętokrzyskie and Małopolskie Provinces, and for consumers, companies - users (gastronomy) in the assessment of cooperatives from Świętokrzyskie Province. Moreover, cooperatives from Małopolskie Province assessed the validity of the features of the offer both for independent retail grocery stores, and for large retail chains, as very important.

- Ecology of the product was considered as extremely important for wholesalers from the point of view of dairy cooperatives from Świętokrzyskie Province, and for consumers and independent retail grocery stores in the assessment of cooperatives from Małopolskie Province. In the same time, the ecology of the product was considered as very important for consumers from the point of view of dairy cooperatives from Świętokrzyskie Province. Either cooperatives from Świętokrzyskie or Małopolskie Provinces assessed that ecology of the product is very important for companies - users (gastronomy), and for local retail chains. Additionally, cooperatives from Małopolskie Province stated that ecology of the product is very important for large retail chains.

- Healthiness of the product was considered as extremely important for large retail chains in the assessment of dairy cooperatives from Małopolskie Province. In the same time, the healthiness of the product was considered as very important for consumers, companies - users (gastronomy), wholesalers, and local retail chains from the point of view of dairy cooperatives from both the Świętokrzyskie and Małopolskie Provinces. Moreover, cooperatives from Małopolskie Province assessed that the healthiness of the product is very important for independent retail grocery stores.

- The nutritional value was considered as extremely important for local retail chains from the point of view of cooperatives from Małopolskie Province, and as very important for companies - users (gastronomy), and wholesalers in the assessment 
of dairy cooperatives from both Świętokrzyskie and Małopolskie Provinces. In the same time, the nutritional value was considered as very important for consumers and local retail chains from the point of view of cooperatives from Świętokrzyskie Province. Cooperatives from Małopolskie Province stated that the nutritional value is quite important for consumers and independent retail grocery stores, and very important for large retail chains.

- The width of the assortment was considered as very important for consumers, companies - users (gastronomy), wholesalers, and local retail chains by both dairy cooperatives from Świętokrzyskie and Małopolskie Provinces. Additionally, cooperatives from Małopolskie Province assessed the width of the assortment as very important for independent retail grocery stores and large retail chains.

- Differentiation was considered as very important for consumers, wholesalers, and local retail chains in the assessment of both dairy cooperatives from Świętokrzyskie and Małopolskie Provinces. For companies - users (gastronomy) the differentiation was considered as extremely important from the point of view of dairy cooperatives from Małopolskie Province, and as very important in the assessment of cooperatives from Świętokrzyskie Province. Moreover, cooperatives from Małopolskie Province stated that differentiation is quite important for independent retail grocery stores and large retail chains.

- Product specialization was considered as very important for companies - users (gastronomy) and wholesalers from the point of view of both dairy cooperatives from Świętokrzyskie and Małopolskie Provinces. For consumers the product specialization was assessed as extremely important by cooperatives from Świętokrzyskie Province, and as very important by cooperatives from Małopolskie Province. In the same time, for local retail chains the product specialization was considered as very important by cooperatives from Świętokrzyskie Province, and as quite important by cooperatives from Małopolskie Province. Additionally, cooperatives from Małopolskie Province stated that the product specialization is very important for independent retail grocery stores, and little important for large retail chains.

\section{Discussion}

As can be seen, accordingly to cooperatives' executives for different types of customers other features of the offer are extremely important. The question is if the cooperatives know which of the features are valid for different kind of customers, do they take actions to meet these expectations? Comparing previously conducted research results with research results of dairy cooperatives it is seen that cooperatives not always meet these expectations, especially when comparing the responses of executives and students i.e. consumers of cooperatives' products and future managers.

There was conducted the research among students of business studies from Poland and Ukraine who had to assess products offered by cooperatives in the field of ecology, quality, and package. The research had aimed to show how future managers, i.e. current students of business studies from Poland and Ukraine, perceive products 
offered by cooperatives. Respondents were asked to assess the extent to which cooperatives pursue the following activities: offering organic products, offering products of high nutritional value, offering natural products, offering products with health claims, offering products produced with high quality ingredients, offering comprehensive products to the number of varieties and types, offering products tagged its brand, ensuring high quality of implementation, offering products in attractively designed packages, offering products in packages visually matched to other, offering products in convenient packages, and offering visually attractive products. These activities were divided and assigned to such fields as ecology, quality, and package. The research results showed that the respondents considered that cooperatives offer products in the average extend in all indicated fields [6].

In another research students were asked to assess the extent to which nationwide and regional dairy cooperatives pursue the following activities in the field of the ecology of products: offering organic products, offering natural products, offering products of high nutritional value, and offering products with health claims. Considering the data analysis, received as a result of conducting research, it turned out that actions of dairy cooperatives both from Poland, and from Ukraine in the sphere of the ecology of the products had been mostly averagely assessed. Only respondents from Poland perceived that nationwide dairy cooperatives offer natural products, and offer products of high nutritional value in the large extent. Responses of all respondents occurred that they better assess activities of nationwide dairy cooperatives than regional ones in the offering organic products, offering natural products, and offering products of high nutritional value. Regional dairy cooperatives on the other hand, were better assessed in the offering products with health claims [5].

D. V. Thompson, R. W. Hamilton, and R. T. Rust had created an analytical model which showed that choosing the number of features that maximizes initial choice results in the inclusion of too many features, potentially decreasing customer lifetime value. Authors suggest that firms should consider having a larger number of more specialized products, each with a limited number of features, rather than loading all possible features into one product [19].

Many researchers have created various tools useful both for managers in assessing the validity of the features of the offer for customers in the area of the product, and for customers to find out more about features of the product. A.-M. Popescu and O. Etzioni, in their article introduced OPINE, an unsupervised information extraction system which mines reviews in order to build a model of important product features, their evaluation by reviewers, and their relative quality across products. They decomposed the problem of review mining into the following main subtasks: I. Identify product features, II. Identify opinions regarding product features, III. Determine the polarity of opinions, and IV. Rank opinions based on their strength. According to authors given a particular product and a corresponding set of reviews, OPINE solves the opinion mining tasks outlined above and outputs a set of product features, each accompanied by a list of associated opinions which are ranked based on strength [17]. In order to help the customer and the manufacture/merchant R. Kumar $\mathrm{V}$ and K. Raghuveer have proposed a semantic based approach to mine different product features and to find the opinion summarization about each of these extracted 
product features by means of web user opinion expressed through the customer reviews using typed dependency relations [13].

\section{Conclusion}

Basing on the research results it is seen that cooperatives from Świętokrzyskie and Małopolskie Provinces rather differently assess the validity of the features of the offer for customers in the area of the product. What is also seen is that for different types of customers other features of the offer are extremely important. According to dairy cooperatives from Świętokrzyskie Province opinions' extremely important for consumers is product specialization, for companies - users (gastronomy) are product components, for wholesalers are product components, naturalness of the product, and ecology of the product. Other features of the offer for these types of customers are very important. For local retail chains, in contrast, all indicated features of the offer are the same very important. On the other hand, dairy cooperatives from Małopolskie Province stated that extremely important for consumers are naturalness of the product, and ecology of the product, for companies - users (gastronomy) are naturalness of the product, and differentiation, for wholesalers are product components, for independent retail grocery stores is ecology of the product, for large retail chains are product components and healthiness of the product, and for local retail chains is the nutritional value. Moreover, what is seen in the research results that other features of the offer for companies - users (gastronomy) and wholesalers are very important. In contrast, among other features that are very important, there are also features that are quite important, i.e. for consumers - the nutritional value, for independent retail grocery stores - the nutritional value, and differentiation, for large retail chains differentiation, and for local retail chains - product specialization. However, for large retail chains such feature of the offer as product specialization is little important.

The results of the research are valid information for cooperatives, because basing on the knowledge on customers' product preferences cooperatives can meet the customers' expectations. Meeting customers' desires for product features is crucial to the cooperatives' revenues from sales and may lead to market advantage over competition.

\section{References}

1. Archak, N., Ghose, A., Ipeirotis, P.G.: Deriving the Pricing Power of Product Features by Mining Consumer Reviews. Management Science 8(57), 1485-1509 (2011).

2. Burnett, J.: Core Concepts of Marketing. 2nd edn. John Wiley and Sons Ltd, New York (2003).

3. Cagan, M.: Behind Every Great Product. 1st edn., Silicon Valley Product Group, San Francisco (2005).

4. Cagan, M.: How to Write a Good PRD. 1st edn., Silicon Valley Product Group, San Francisco (2005). 
5. Konieczna, I., Garasym, P.: Activities of the Ecology of Products - Their Perception on the Example of Dairy Co-operatives in Poland and Ukraine. In: M. Mokrys, S. Badura (eds.) Proceedings in Electronic International Interdisciplinary Conference (EIIC 2015), vol. 4, pp. 99-104. University of Žilina, Žilina (2015).

6. Konieczna, I., Garasym, P.: Perception of the Products Offered by Cooperatives in Poland and Ukraine, In: S. Hittmar (eds.) Theory of Management, vol. 3, pp. 139-145. University of Žilina, Žilina (2014).

7. Konieczna, I.: The Importance of the Types of Customers. A Comparison Between Dairy Cooperatives from Świętokrzyskie and Małopolskie Provinces. In: Jurcic, A., Oreski, D., Mikic, M. (eds.) Economic and Social Development (Book of Proceedings), 21st International Scientific Conference on Economic and Social Development (May 2017), pp. 561-570, Varazdin Development and Entrepreneurship Agency, John Naisbitt University, University North, Faculty of Management University of Warsaw, Belgrad (2017).

8. Konieczna, I.: The Importance of Types of Customers for Housing Cooperatives from the Świętokrzyskie Province. In: Jedlička P. (eds.) Hradec Economic Days 2014, vol. 4, pp. 307-311, University of Hradec Kralove, Hradec Kralove (2014).

9. Konieczna, I.: The Validity of the Features of the Offer for Clients in the Sphere of Sales Marketing - the Assessment of Dairy Cooperatives from Świętokrzyskie Province. In: Primorac, Z., Bussoli, C., Recker, N. (eds.) 16th International Scientific Conference on Economic and Social Development - Legal Challenges of Modern World, September 2016, pp. 817-826, Varazdin Development and Entrepreneurship Agency, University of Split, University North, Split (2016).

10. Konieczna, I.: The Validity of the Features of the Offer to the Customer in the Area of Product in the Assessment of the Dairy Cooperatives from the Świętokrzyskie Voivodeship. In: Mikuła, B., Rojek, T. (eds.) Knowledge-Economy-Society. Reorientation of Paradigms and Concepts of Management in the Contemporary Economy, pp. 475-484. Cracow University of Economics, Cracow (2015).

11. Kotler, P, Armstrong, G.: Principles of Marketing. 13th edn. Pearson Education Inc., Upper Saddle River (2010).

12. Kotler, P., Keller, K. L., Brady, M., Goodman, M., Hansen, T.: Marketing Management. 1st edn. Pearson Education Limited, Harlow (2009).

13. Kumar V, R., Raghuveer, K.: Web User Opinion Analysis for Product Features Extraction and Opinion Summarization. International Journal of Web \& Semantic Technology 4(3) 69-82 (2012), DOI: 10.5121/ijwest.2012.3407.

14. Lamb, C. W., Hair, J. F. Jr., McDaniel, C.: Essentials of Marketing. 7th edn. Ohio SouthWestern Cengage Learning, Mason (2012).

15. Levitt, T.: The Marketing Imagination. 5th edn. The Free Press, New York (1986).

16. Meywis, T., Janiszewski, C.: Consumers' Beliefs about Product Benefits: The Effect of Obviously Irrelevant Product Information. Journal of Consumer Research, Inc. 28(4), 618635 (2002).

17. Popescu, A. M., Etzioni, O.: Extracting Product Features and Opinions from Reviews. In: Kao, A., Poteet, S. R. (eds) Natural Language Processing and Text Mining, pp. 9-28, Springer, London (2007).

18. Pride, W. M., Ferrell, O. C., Lucas, B. A., Schembri, S., Niininen, O.: Marketing Principles. 2nd edn. Cengage Learning Australia Pty Limited, Sydney (2015).

19. Thompson, D. V., Hamilton, R. W., Rust, R. T.: Feature Fatigue: When Product Capabilities Become Too Much of a Good Thing. Journal of Marketing Research 42(November 2005), 431-442 (2005). 